Макаревская Н. Ю.

N. Yu. Makarevskaya

ДАЛЬНИЙ ВОСТОК РОССИИ И СТРАНЫ СЕВЕРО-ВОСТОЧНОЙ АЗИИ:

СТРАТЕГИЧЕСКИЙ УРОВЕНЬ СОТРУДНИЧЕСТВА И МЕЖКУЛЬТУРНЫЕ КОММУНИКАЦИИ НА СОВРЕМЕННОМ ЭТАПЕ

\title{
THE FAR EAST OF RUSSIA AND THE COUNTRIES OF NORTH EAST ASIA: A STRATEGIC LEVEL OF COOPERATION AND INTERCULTURAL COMMUNICATION AT THE PRESENT STAGE
}

Макаревская Нина Юрьевна - аспирантка Комсомольского-на-Амуре государственного университета (Россия, Комсомольск-на-Амуре); 681013, Комсомольск-на-Амуре, пр. Ленина, 27; тел.: +7 (914) 154-04-48. E-mail: ninamakarevskaya@yandex.ru.

Ms. Nina Yu. Makarevskaya - a postgraduate student, History and Archival Sciences Department, Komsomolskon-Amur State University (Russia, Komsomolsk-on-Amur); 681013, Komsomolsk-on-Amur, 27 Lenin str.; tel.: + 7 (914) 154-04-48. E-mail: ninamakarevskaya@yandex.ru.

Аннотация. В статье рассматриваются взаимоотношения между Россией и странами Северо-Восточной Азии (CBA) на современном этапе в контексте межкультурного диалога. Отмечены серьёзное сближение стран СВА - Японии, Республики Корея с Россией; восстановление связей России с Монголией. Автором обозначена особая значимость в данном контексте Дальневосточного федерального округа России. Рассматриваются юридическая и организационная базы межкультурного сотрудничества между российским Дальним Востоком и странами Северо-Востока Азии, такими как Япония, Республика Корея и Монголия. Выявлено, что взаимоотношения между российским Дальним Востоком и северо-восточными странами Азии в целом переходят на новый стратегический уровень развития. Определено, что улучшению взаимоотношений, повышению степени доверия между Россией и странами СВА в большой степени способствует межкультурный диалог.

Summary. The article discusses the relationship between Russia and the countries of Northeast Asia at the present stage in the context of intercultural dialogue. A serious rapprochement between the countries of Northeast Asia, such as Japan, the Republic of Korea and Russia, and the restoration of Russia's ties with Mongolia is noted. The author designates special significance in this context of the Far Eastern Federal District of Russia. The legal and organizational framework for intercultural cooperation between the Russian Far East and the countries of Northeast Asia, such as Japan, the Republic of Korea and Mongolia, is considered. It was revealed that the relationship between the Russian Far East and the NEA countries as a whole is moving to a new strategic level. It has been determined that the improvement of mutual relations, the increase in the degree of trust between Russia and the NEA countries is largely promoted by intercultural dialogue.

Ключевые слова: Дальний Восток России, Япония, Южная Корея, Монголия, Северо-Восточная Азия, межкультурный диалог, стратегическое партнёрство.

Key words: Far East of Russia, Japan, South Korea, Mongolia, North-East Asia, intercultural dialogue, strategic partnership.

\section{УДК 008.2}

В связи с изменениями в международном порядке, связанными с переходом к многополярности, глобализацией и формированием сетей и коалиций, на современном этапе государства вынуждены менять приоритеты в отношениях с другими странами. Особенно наглядны такие перемены в Азиатско-Тихоокеанском регионе, одном из крупнейших центров мировой активности. 
Макаревская Н. Ю.

ДАЛЬНИЙ ВОСТОК РОССИИ И СТРАНЫ СЕВЕРО-ВОСТОЧНОЙ АЗИИ: СТРАТЕГИЧЕСКИЙ УРОВЕНЬ СОТРУДНИЧЕСТВА

И МЕЖКУЛЬТУРНЫЕ КОММУНИКАЦИИ НА СОВРЕМЕННОМ ЭТАПЕ

Также можно отметить серьёзное сближение стран СВА - Японии, Республики Корея с Россией. Россия в свою очередь пытается выстраивать более тесные отношения с Монголией. Особую значимость в данном контексте приобретает ДФО России. Сегодня можно говорить о переходе взаимоотношений между российским Дальним Востоком и странами СВА на новый стратегический уровень. На это указывают достаточно проработанные юридическая и организационная базы, увеличивающееся с каждым годом количество встреч на высшем и высоком уровнях. Особый акцент правительства России и государств Северо-Восточной Азии делают на межкультурные коммуникации. Развивая межкультурный диалог, страны закладывают фундамент для будущих поколений, укрепляя взаимопонимание и доверие между народами.

Например, несмотря на то, что отношения России и Японии, даже в отсутствие мирного договора, в последние годы находятся в лучшем состоянии за всю их историю, со стороны Японии сохраняется недоверие и осторожность по отношению к России. Связано это, во-первых, с нерешённостью территориального вопроса, во-вторых, с проамериканской настроенностью японцев. Тем не менее наши страны объединяет общая история, у японцев повышается интерес к изучению русского языка и русской культуры.

Гуманитарные отношения между Россией и Японией регулируются Московской декларацией 1998 года об установлении созидательного партнёрства между Российской Федерацией и Японией [12], Соглашением между Правительством Российской Федерации и Правительством Японии о культурных связях от 21 июля 2002 г. Стороны договорились содействовать обменам учёными, педагогическими и научными работниками, студентами и аспирантами, деятелями искусства и др., проведению мероприятий, призванных содействовать ознакомлению народов своих государств с культурой, историей, общественным устройством и образом жизни другой страны. В Москве 10 января 2003 г. был подписан Российско-японский план действий. Документ охватывает многие области двусторонних отношений - от экономики до гуманитарной сферы - и нацелен на новое качество двусторонних отношений исходя из осознания важности дальнейшего углубления взаимопонимания, уважения друг друга и укрепления взаимного доверия [20]. Укреплению взаимопонимания между народами Японии и России способствует осуществление безвизовых обменов между жителями островов Итуруп, Кунашир, Шикотан и Хабомаи и японскими гражданами, а также другими контактами [1].

Несмотря на то, что юридическая база для развития взаимоотношений достаточно проработана, японская сторона не готова выйти на новый доверительный уровень межкультурной коммуникации, не готова делиться опытом. Тем не менее на сегодняшний день сотрудничество в сферах образования и искусства вносят весомый вклад в поступательное развитие российско-японских отношений в целом. И российская, и японская стороны осознают, что, развивая межкультурный диалог, закладывают фундамент для будущих поколений, не связанных с историческими предрассудками и недоверием, которые смогут вывести российско-японские отношения на качественно новый уровень.

На это направлена деятельность правительственных и неправительственных организаций. Японской стороной культурные проекты реализуются прежде всего неправительственными организациями, такими как Японский фонд, созданный в 1972 году, АНО «Японский центр» (в настоящее время зарегистрирована как автономная некоммерческая организация «Японский центр по развитию торгово-экономических связей»). На Дальнем Востоке России филиалы Центра созданы в Хабаровске, Владивостоке и Сахалине. Деятельность данных организаций направлена в том числе на углубление понимания Японии и японской культуры, содействие наведению мостов между Россией и Японией.

С сентября 2008 г. осуществляет деятельность преемник Росзарубежцентра - Федеральное агентство по делам СНГ, соотечественников, проживающих за рубежом, и по международному гуманитарному сотрудничеству (Россотрудничество). Основными партнёрами Россотрудничества 


\section{Учёные записки}

Комсомольского-на-Амуре государственного технического университета

являются Российская ассоциация международного сотрудничества (РАМС) и входящие в неё общественные объединения, в том числе российские общества дружбы с зарубежными странами. Среди входящих в РАМС организаций стоит отметить Общество «Россия и Япония», созданное в 1991 году с целью содействия процессу развития обменов между двумя странами. Организациипартнёры Общества на Дальнем Востоке России: Клуб при Японском центре во Владивостоке, Общество дружбы «Россия - Япония» Хабаровской региональной общественной организации «Союз обществ дружбы с зарубежными странами», Якутское региональное отделение Общества «Россия - Япония» [9]. Большое количество культурных мероприятий проходит при содействии Генерального консульства Японии в Хабаровске и Генерального консульства Японии во Владивостоке.

Дальневосточный регион играет особенную роль в улучшении взаимопонимания между народами России и Японии. Между российской и японской сторонами на приграничных территориях проводится большое количество мероприятий. В 2013 году в Хабаровске прошёл месяц японской культуры «Японская весна - 2013». В марте в городах ДФО традиционно проводится фестиваль японского кино. Ярким культурным событием не только Дальнего Востока, но и всей России является фестиваль биеннале визуальных искусств (Владивосток). С апреля 2003 г. по март 2004 г. в нашей стране проходил фестиваль японской культуры. С 2005 года проходит фестиваль российской культуры в Японии с программой до 2021 года. Фестиваль знакомит японцев с балетом, музыкой, театром, цирком и другими проявлениями русского искусства [5].

В 2017 году проведены «Русские сезоны» в Японии. В этом мероприятии задействована и территория российского Дальнего Востока. Так, концерты к 135-летию со дня рождения великого русского композитора И. Стравинского в рамках Второго дальневосточного фестиваля «Мариинский» прошёл под эгидой «Русских сезонов». В фестивале приняли участие российские и японские артисты [10]. Две тысячи восемнадцатый год объявлен «перекрёстным» годом России в Японии и Японии в России. Одним из самых ярких проектов, проходящих в рамках Года Японии в России, стал японский праздник - концерт «Поезд дружбы», прошедший в городах Дальнего Востока и Сибири. С 2009 года проводятся российско-японские форумы ректоров, с 2013-го активно осуществляются межвузовские связи [14].

Развитие сотрудничества между Россией и Монголией в области образования и подготовки кадров имеет первостепенное значение для дальнейшего развития всесторонних связей между нашими странами. Однако и в этой сфере, и в российско-монгольском сотрудничестве в целом существует ряд проблем. Те, кто знали русский язык, уже его забыли, а нынешним монгольским юношам и девушкам предоставляется широкий выбор. Позиции России в Монголии постепенно ослабевают, в том числе и в сфере образования. Особую значимость приобретает более тесное сотрудничество сибирских и дальневосточных регионов РФ с Монголией, особенно вопрос о культурном синтезе, возникающем в ходе сотрудничества между монголо-язычными республиками России и Монголией. Важным фактором развития между этими двумя странами сотрудничества являются возможности широкого межкультурного взаимодействия [23].

На сегодняшний день между Россией и Монголией подписано большое количество договоров и соглашений, в том числе в области гуманитарного сотрудничества. Например, в 1993 году был заключён Договор о дружественных отношениях и сотрудничестве, а в 2009-м - Декларация о развитии стратегического партнёрства между Россией и Монголией. Двусторонние отношения также опираются на Улан-Баторскую декларацию от 2000 года и Московскую декларацию от 2006 года; также сторонами заключены Соглашение о культурном и научном сотрудничестве от 5 апреля 1995 г. (дополнено Программой 2003 года), Соглашение о сотрудничестве в области образования, Соглашение о взаимном признании документов об образовании, учёных степенях и учёных званиях от 2003 года. Кроме того, подписано большое количество соглашений о сотрудничестве российских и монгольских организаций: Академии наук Монголии и Российской академии наук, 
Макаревская Н. Ю.

ДАЛЬНИЙ ВОСТОК РОССИИ И СТРАНЫ СЕВЕРО-ВОСТОЧНОЙ АЗИИ: СТРАТЕГИЧЕСКИЙ УРОВЕНЬ СОТРУДНИЧЕСТВА

И МЕЖКУЛЬТУРНЫЕ КОММУНИКАЦИИ НА СОВРЕМЕННОМ ЭТАПЕ

Российского гуманитарного научного фонда и Министерства образования Монголии; принята Программа сотрудничества между Министерством культуры России и Министерством образования, культуры, науки и спорта Монголии [2]. С ноября 2014 г. между Россией и Монголией введён безвизовый режим [11].

Сотрудничеству в области образования и науки, физкультуры и спорта, развитию туризма и прочего между Россией и Монголией способствует Российско-монгольская межправительственная комиссия по торгово-экономическому и научно-техническому сотрудничеству (соглашение от 25 марта 2002 г.) [16]. Созданная в том же году комиссия по сотрудничеству в области архивов содействует организации историко-документальных выставок, обмену опытом работы архивных учреждений, повышению квалификации архивных работников на базе архивных и научных учреждений России и Монголии [25].

С каждым годом увеличивается количество квот для студентов из Монголии. В Монголии действуют филиалы российских вузов, в том числе Восточно-Сибирского государственного технологического университета. Также проводятся выставки образовательных услуг: 15 марта 2018 г. на базе Центра науки и культуры Монголии прошла III ежегодная «Российская образовательная выставка - 2018», в которой приняли участие вузы 16 регионов России, в том числе Владивостокский университет экономики и сервиса. Кроме того, между странами происходит обмен учёными и специалистами, проводятся совместные конференции, семинары, научно-технические выставки, симпозиумы, реализовываются научно-исследовательские и технологические проекты, проводятся научные конкурсы. Большое внимание уделяется изучению русского языка. С 2006 года русский язык изучается в монгольских школах в качестве второго обязательного иностранного языка после английского.

Традиционно в городах России проходят дни монгольской культуры, в Монголии - дни российско-монгольской дружбы. В 2016 году прошли совместные культурные мероприятия в рамках празднования 95-летия установления дипломатических отношений между Монголией и Россией. При поддержке правительств двух стран ежегодно проводятся профильные выставки, совместные семинары и обмен делегациями в туристической отрасли [19].

Между Россией и Республикой Корея отсутствуют политические проблемы, способные тормозить развитие взаимоотношений. Однако в целом Южная Корея - не простой для России партнёр. Во-первых, южнокорейские власти в «стратегическом партнёрстве» с Россией предусматривают создание преимуществ над Китаем и Японией в доступе к природным ресурсам российского Дальнего Востока и Сибири, во-вторых, действуют с оглядкой на Вашингтон. Положительным аспектом является тот факт, что Россия является важным для Республики Корея партнёром в деле укрепления мира на Корейском полуострове и в достижении общего процветания государств Северо-Восточной Азии.

Взаимоотношения России и Республики Корея также поступательно развиваются, особенно в сфере культурного взаимодействия при поддержке правительств двух стран. Договор об основах отношений между Россией и Кореей был заключён 29 апреля 1993 г. [4]. Ещё раньше, в 1992 году, между странами было заключено Соглашение о культурном сотрудничестве [21]. В Пхеньяне 09 февраля 2000 г. подписан Договор о дружбе, добрососедстве и сотрудничестве между Российской Федерацией и Корейской Народно-Демократической Республикой. Стороны договорились поддерживать и развивать дружественные отношения [3]. В сентябре 2008 г. состоялся визит Президента Республики Корея Ли Мёнбака в Россию. В ходе встречи на высшем уровне отношения между Россией и Республикой Корея были вынесены на уровень стратегического партнёрства. По итогам встречи президентов двух стран 23 июня 2018 г. стороны договорились активизировать регулярные контакты на высшем уровне, содействовать расширению обменов и сотрудничества между правительствами, парламентами, деловыми и научными кругами, а также обменов в сфере культуры и искусства, в том числе в связи с празднованием в 2020 году 30-й годовщины установ- 


\section{Учёные записки}

Комсомольского-на-Амуре государственного технического университета

ления двусторонних дипломатических отношений между Российской Федерацией и Республикой Корея. Две тысячи двадцатый год объявлен Годом взаимных обменов между Российской Федерацией и Республикой Корея [18]. В результате введения безвизового режима между Российской Федерацией и Республикой Корея увеличилось количество южнокорейских туристов, приезжающих в Россию, и количество российских туристов, посещающих Корею.

Взаимоотношения России и Кореи в области образования и культуры имеют давнюю историю. Корейцы очень серьёзно относятся к образованию. С 16 марта 2015 г. действует Соглашение между правительствами Российской Федерации и Республики Корея об учреждении и условиях деятельности культурных центров в Москве и Сеуле [22]. Такие центры действуют во Владивостоке, Уссурийске, Хабаровске и других городах России. Деятельность центров направлена не только на обучение корейскому языку, но и приобщение к корейской культуре - традиционным национальным танцам и музыке [7]. При университетах создаются клубы любителей корейского языка и культуры [6].

Для Кореи тоже важны национальное культурное возрождение российских корейцев и развитие культуры межэтнических отношений. С этой целью в 2004 году в Хабаровске была создана Ассоциация корейских организаций Дальнего Востока и Сибири. Ассоциация тесно сотрудничает с Ассамблеей народов Хабаровского края, Международной ассоциацией национальных культур, министерством культуры Хабаровского края, краевым научно-образовательным объединением культуры (КНОТОК), Корейским молодёжным центром «Корё» и другими государственными и общественными организациями российского ДВ и Корейского полуострова [15].

Укреплению и развитию корейской диаспоры в России содействует научно-техническое общество «АНТОК», деятельность которого направлена на установление научных и профессиональных связей между представителями диаспоры, популяризацию науки и образования среди молодёжи, развитие сотрудничества между научными сообществами корейцев, проживающих в других странах [13].

Между Дальним Востоком России и Южной Кореей проводится большое количество мероприятий. Традиционным стал фестиваль корейской культуры. На базе дальневосточных университетов совместно с корейскими вузами проводятся молодёжные форумы («Две страны - один путь к успешному будущему»), конкурсы («Арктическая Якутия и Дальний Восток как регионыпартнёры Республики Корея») [17]. Большое количество студентов отправляется в Южную Корею с целью изучения корейского языка по программам Министерства образования Республики Корея и по собственной инициативе.

С 14 по 29 июля 2002 г. при поддержке правительств обеих стран в России прошла акция «Экспресс корейско-российской дружбы - 2002». Поезд совершил маршрут с остановками по семи российским городам: от Владивостока и Хабаровска его маршрут проходил через Иркутск, Новосибирск, Екатеринбург, Москву и завершился в Санкт-Петербурге. Во время поездки пассажиры встречались с главами субъектов Федерации, организовывали семинары и лекции, общались с местным населением.

Две тысячи четырнадцатый год стал годом празднования 150-летней годовщины переселения корейцев в Россию. Этому событию посвящён комплекс мероприятий: научно-практическая конференция, кинофестиваль, музейная экспозиция, фестивали корейской культуры и др.; 20 июля 2016 г. в Хабаровске побывала «Евразийская экспедиция Пусана - 2016»; развиваются лечебнооздоровительный, культурно-познавательный, деловой туризм; проводятся выставки, обучающие семинары по сотрудничеству в сфере туризма между регионами Дальнего Востока и Восточной Сибири РФ и Южной Кореей [24].

Таким образом, можно отметить становление и динамичное развитие взаимоотношений между Россией и Республикой Корея. Благодаря развитию межкультурного диалога значительно улучшились и стабилизировались отношения между Российской Федерацией и Японией. Возрож- 
Макаревская Н. Ю.

ДАЛЬНИЙ ВОСТОК РОССИИ И СТРАНЫ СЕВЕРО-ВОСТОЧНОЙ АЗИИ: СТРАТЕГИЧЕСКИЙ УРОВЕНЬ СОТРУДНИЧЕСТВА

И МЕЖКУЛЬТУРНЫЕ КОММУНИКАЦИИ НА СОВРЕМЕННОМ ЭТАПЕ

даются практически утраченные связи Монголии с нашей страной. На современном этапе благодаря усилиям правительств названных государств взаимоотношения между ними выходят на новый уровень стратегического партнёрства. Улучшению взаимоотношений, повышению степени доверия между Россией и странами СВА в большой степени способствует межкультурный диалог.

\section{ЛИТЕРАТУРА}

1. Берестовой, Д. А. Развитие связей в сфере туризма между Хабаровским краем и Японией [Электронный pecypc]. - Режим доступа: https://cyberleninka.ru/article/n/razvitie-svyazey-v-sfere-turizma-mezhdu-habarovskimkraem-i-yaponiey-1985-2010 (дата обращения: 28.10.2018).

2. Ганхуяг, Э. Россия-Монголия: по пути стратегического партнёрства / Э. Ганхуяг // Вестник РУДН. История России. - 2017. - Т. 16. - № 3. - С. 462-476.

3. Договор о дружбе, добрососедстве и сотрудничестве между Российской Федерацией и Корейской Народно-Демократической Республикой от 09 февраля 2000 г. [Электронный ресурс]. - Режим доступа: http://www.mid.ru/foreign_policy/international_contracts/2_contract/-/storage-viewer/bilateral/page-206/46817 (дата обращения: 10.02.2018).

4. Договор об основах отношений Российской Федерации и Республики Корея [Электронный ресурс]. $-\mathrm{Pe}-$ жим доступа: http://docs.cntd.ru/document/901839752 (дата обращения: 08.02.2018).

5. Киба, Д. В. Культурные связи России и Японии в постсоветский период / Д. В. Киба // Современные исследования социальных проблем. - 2012. - № 10. - С. 49.

6. Клуб любителей корейского языка и культуры [Электронный ресурс]. - Режим доступа: http://www.dvgups.ru/press-main-page/9539-klub-lyubitelej-korejskogo-yazyka-i-kultury (дата обращения: 11.02.2018).

7. Корейский молодёжный культурно-просветительский центр [Электронный ресурс]. - Режим доступа: http://www.arirang.ru/youth/piter.htm (дата обращения: 11.02.2018).

8. Корейцы устроили во Владивостоке бум. Туристический [Электронный ресурс]. - Режим доступа: http://primpress.ru/article/25603 (дата обращения: 10.02.2018).

9. Киба, Д. В. Меморандум о расширении обменов между Российской Федерацией и Японией в культурной и других областях: учеб. пособие [Электронный ресурс] / Д. В. Киба. - Режим доступа: http://docs.cntd.ru/document/1902065 (дата обращения: 28.10.2018).

10. Межгосударственные отношения России и Японии [Электронный ресурс]. - Режим доступа: http://ria.ru./spravka/20151019/1301742918.html (дата обращения: 28.10.2018).

11. Международные договоры Российской Федерации в сфере туризма [Электронный ресурс]. - Режим доступа: https://www.russiatourism.ru/contents/deyatelnost/mezhdunarodnaya-deyatelnost/mezhdunarodnye-dogovoryrossiyskoy-federatsii-v-sfere-turizma (дата обращения: 27.01.2018).

12. Московская декларация об установлении созидательного партнёрства между Российской Федерацией и Японией [Электронный ресурс]. - Режим доступа: http://docs.cntd.ru/document/901724336 (дата обращения: 28.10.2018).

13. Научно-техническое общество «АНТОК» [Электронный ресурс]. - Режим доступа: https://aksts.ru/ (дата обращения: 11.02.2018).

14. Новости [Электронный ресурс] // сайт Генерального консульства Японии в Хабаровске. - Режим доступа: https://www.khabarovsk.ru.emb-japan.go.jp/itprtop_ru/index.html (дата обращения: 09.01.2018).

15. Об Ассоциации [Электронный ресурс] // сайт Ассоциации корейских организаций Дальнего Востока и Сибири. - Режим доступа: http://www.akodvs.ru/index/0-2 (дата обращения: 08.02.2018).

16. Протокол 18-го заседания Российско-монгольской межправительственной комиссии по торговоэкономическому и научно-техническому сотрудничеству: Улан-Батор, 13-15 декабря 2014 г. [Электронный pecypc]. - Режим доступа: http://194.87.255.243/upload/iblock/145/18.pdf?spetial=Y (дата обращения: 27.01.2018).

17. СВФУ объявил конкурс эссе об Арктике и Дальнем Востоке для студентов из Южной Кореи [Электронный ресурс]. - Режим доступа: https://tass.ru/obschestvo/4807747(дата обращения: 10.02.2018).

18. Совместное заявление Российской Федерации и Республики Корея [Электронный ресурс]. - Режим доступа: http://kremlin.ru/supplement/5321/print (дата обращения: 07.12.2018). 
19. Современные российско-монгольские отношения: модели и сценарии / отв. ред. В. А. Родионов. - УланУдэ: Изд-во Бурят. гос. ун-та, 2013. - 248 с.

20. Соглашение между Правительством Российской Федерации и Правительством Японии о культурных связях [Электронный ресурс]. - Режим доступа: http://docs.cntd.ru/document/901809485 (дата обращения: 28.10.2018).

21. Соглашение между Правительством Российской Федерации и Правительством Республики Корея о культурном сотрудничестве [Электронный ресурс]. - Режим доступа: http://www.mid.ru/foreign_policy/international_contracts/2_contract/-/storage-viewer/bilateral/page-360/48719 (дата обращения: 07.12.2018).

22. Соглашение между Правительством Российской Федерации и Правительством Республики Корея об учреждении и условиях деятельности культурных центров [Электронный ресурс]. - Режим доступа: http://www.mid.ru/foreign_policy/international_contracts/2_contract/-/storage-viewer/bilateral/page-56/44313 (дата обращения: 07.12.2018).

23. Фалилеева, Н. В. Проблемы взаимодействия России и Монголии в сфере образования / Н. В. Фалилеева // Приоритеты России. - 2013. - № 12. - С. 10.

24. «Экспресс дружбы» идёт по России: газета «Тихоокеанская звезда» [Электронный ресурс]. - Режим доступа: https://www.toz.khv.ru/special_issues/arkhiv/2002_07_16_ekspress_druzhby_idet_po_rossii (дата обращения: 04.02.2018).

25. 23-е заседание Российско-монгольской комиссии по сотрудничеству в области архивов [Электронный pecypc] // сайт Федерального архивного агентства. - Режим доступа: http://archives.ru/press/23-06-2018mongolia.shtml (дата обращения: 27.01.2018). 